\title{
Biology and Management of Ragweed Parthenium (Parthenium hysterophorous L.) in Tomato, Pepper, Cucurbit, and Strawberry Production' ${ }^{1}$
}

\author{
Nathan S. Boyd, Shaun M. Sharpe, Chris Marble, and Shawn Steed ${ }^{2}$
}

\section{Introduction}

The purpose of this document is to provide general management options for commercial specialty crop growers dealing with ragweed parthenium (Parthenium hysterophorus L.), hereafter referred to as parthenium.

Parthenium is an herbaceous annual or short-lived perennial that is a member of the Asteraceae family. It is highly problematic in agricultural and natural ecosystems in many countries throughout the world and can have negative impacts on livestock, human health, crop production, and ecosystem health (Adkins and Shabbir 2014). Parthenium can be invasive due to its allelopathic properties as well as its prolific seed production, with up to 20,000 seeds produced per plant and seeds persisting within the soil for 4-6 years on average (Adkins and Shabbir 2014; Belgeri et al. 2012). The lack of susceptibility of this species to some commonly used herbicides combined with its invasive potential makes it difficult to manage within agricultural ecosystems.

\section{Species Description}

Class: Dicotyledonous plants

Family: Asteraceae

Tribe: Heliantheae

Other Common Names: false ragweed, Santa-Maria, Santa Maria feverfew, whitetop weed, congress weed, famine weed.

Life Span: Annual or short-lived perennial.

Habitat: Wastelands, disturbed ecosystems, forests, flood plains, orchards, agricultural fields, pastures, roadsides, and railways (Kuar et al. 2014).

Distribution: The native range of this species is somewhat unclear but suspected to be around the Gulf of Mexico, including South and Central America. Some authors consider it native to the southern United States, but opinions vary

1. This document is ENH1349, one of a series of the Environmental Horticulture Department, UF/IFAS Extension. Original publication date December 2021. Visit the EDIS website at https://edis.ifas.ufl.edu for the currently supported version of this publication.

2. Nathan S. Boyd, associate center director and professor of weed management of strawberries and vegetables, Horticultural Sciences Department, UF/IFAS Gulf Coast Research and Education Center; Shaun M. Sharpe, postdoctoral associate, Horticultural Sciences Department; Chris Marble, associate professor, ornamental \& landscape weed management, Environmental Horticulture Department, UF/IFAS Mid-Florida REC; and Shawn Steed, Extension agent II, MS, environmental horticulture/ornamental, UF/IFAS Extension Hillsborough County; UF/IFAS Extension, Gainesville FL 32611.

The use of trade names in this publication is solely for the purpose of providing specific information. UF/IFAS does not guarantee or warranty the products named, and references to them in this publication do not signify our approval to the exclusion of other products of suitable composition.

Use pesticides safely. Read and follow directions on the manufacturer's label.

The Institute of Food and Agricultural Sciences (IFAS) is an Equal Opportunity Institution authorized to provide research, educational information and other services

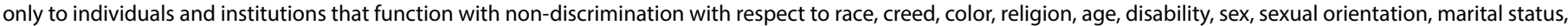

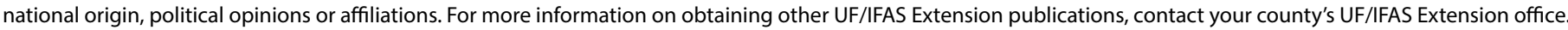
U.S. Department of Agriculture, UF/IFAS Extension Service, University of Florida, IFAS, Florida A \& M University Cooperative Extension Program, and Boards of County Commissioners Cooperating. Andra Johnson, dean for UF/IFAS Extension. 
(Navie et al. 1996). It now occurs in over 54 countries and can be found in South America, North America, South and Southeastern Asia, the Middle East, North and East Africa, and southern Africa (Adkins and Shabbir 2014).

Growth Habit: Herbaceous annual or short-lived perennial.

Seedlings: Parthenium cotyledons occur on short stalks and are paddle-shaped. The first true leaves are oval-shaped and covered in fine, white hairs. A basal rosette forms, containing feather-like lobed leaves (pinnatifid to bipinnatifid) that are pubescent (hairy) with white veins (Figure 1).

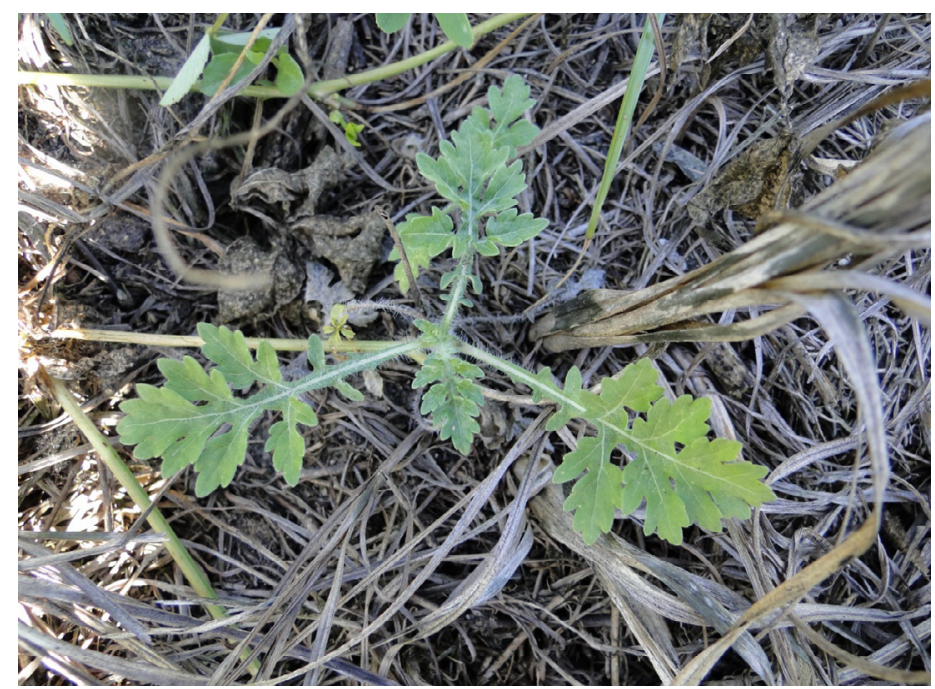

Figure 1. A ragweed parthenium seedling (early rosette stage). Credits: Nathan S. Boyd, UF/IFAS

Shoots: Stems are erect, hairy (hirsute), longitudinally grooved, and octangular (8-sided), and they may become tough and woody with age (Kuar et al. 2014). Leaves on the stem are either slightly lobed to entire, pubescent on both sides, and light green in color (Stamps 2016) (Figure 2).

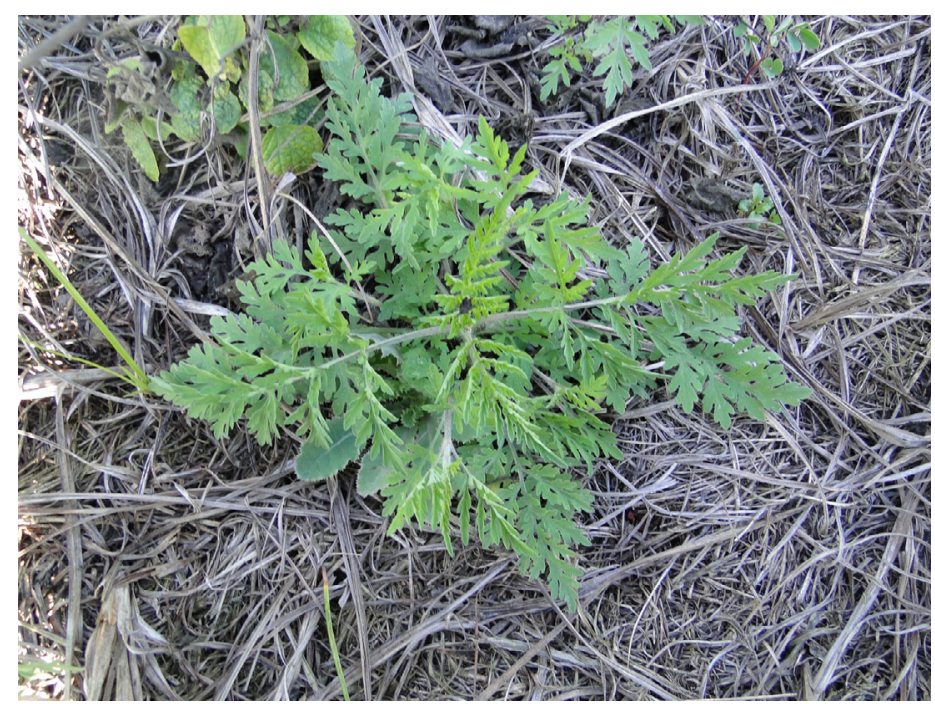

Figure 2. Ragweed parthenium rosette prior to the bolting stage. Credits: Nathan S. Boyd, UF/IFAS
Roots: Branching fibrous roots with a tap root that may reach $2 \mathrm{~m}$ in length (Kuar et al. 2014).

Inflorescence: Flowers arise at the stem apex.They are small and white with tiny ray florets arranged in five parts (Stamps 2016) (Figure 3).

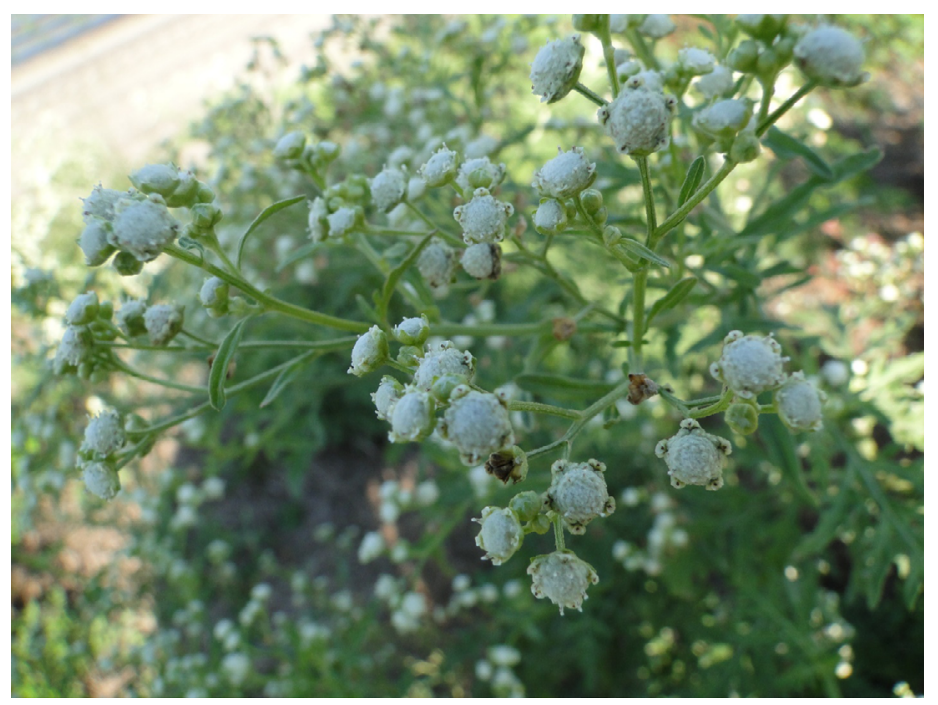

Figure 3. Ragweed parthenium inflorescence demonstrating flowers and ray florets.

Credits: Nathan S. Boyd, UF/IFAS

Fruit and Seeds: Five achenes (small dry fruit) are produced per flower. Achenes are wedge shaped and approximately $2 \mathrm{~mm}$ long.

Similar Species: Ragweed parthenium closely resembles common ragweed (Ambrosia artemisiifolia) while at the rosette stage. The two species can easily be distinguished by the presence of white leaf veins and the characteristic ribbed stem found on ragweed parthenium.

Plant Biology: Ragweed parthenium demonstrates autotoxicity (Kumari and Kohli 1987). This is a form of allelopathy (where a plant possesses a chemical which inhibits another plant) that inhibits the growth and reproduction of members of the same species. Ragweed parthenium may flower as early as one month old and may continue flowering for an additional 6 to 8 months (Adkins and Shabbir 2014). They are not frost tolerant but will tolerate mild winters (Adkins and Shabbir 2014). Seeds do not demonstrate dormancy and may germinate whenever sufficient moisture is present (Kuar et al. 2014). 


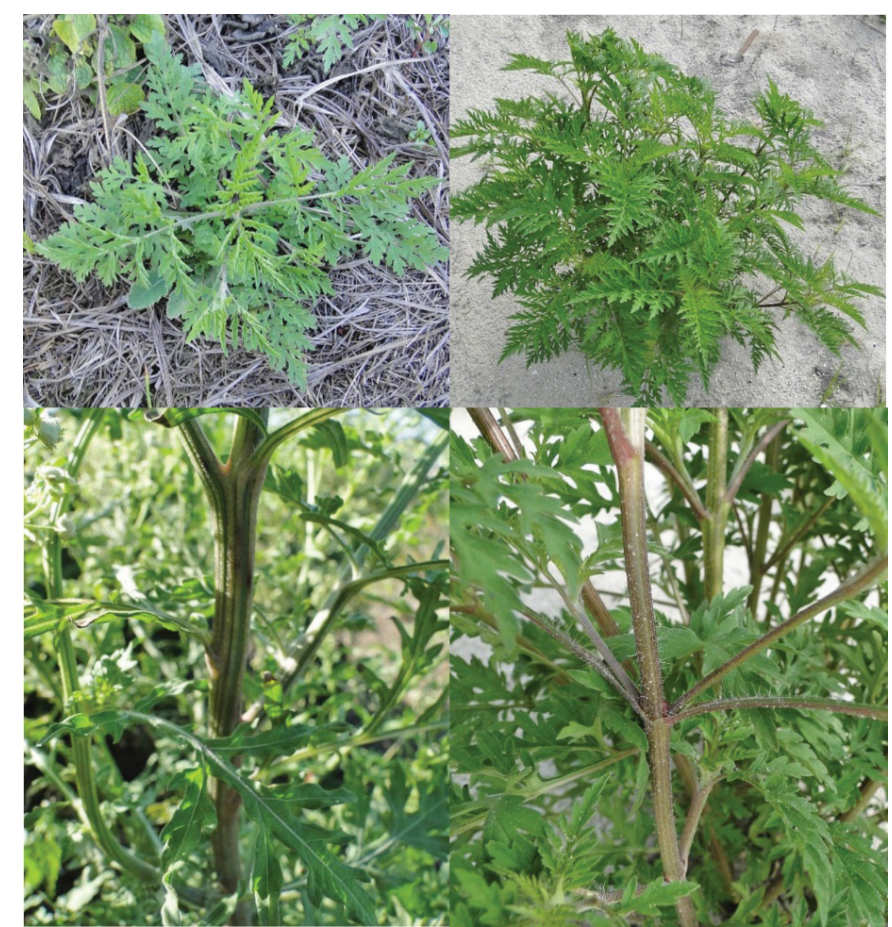

Figure 4. Ragweed parthenium (upper and lower left) and common ragweed (upper and lower right). Note the white leaf veins and ridged stem on ragweed parthenium versus the green leaf veins and smooth stem on common ragweed.

Credits: Nathan S. Boyd, UF/IFAS

\section{Management}

\section{Cultural Control}

Clean equipment prior to moving between fields to limit seed spread. Seed dispersal is primarily through water currents, animals, wind (to a lesser degree), machinery and vehicles. The latter is probably the most common source of long-distance dispersal (Kuar et al. 2014).

Ragweed parthenium growth and reproduction can be suppressed with competitive plant canopies. Cover crops that establish and grow rapidly to form a competitive canopy will hinder ragweed parthenium growth during fallow periods. Rapid establishment and crop growth can also be used within some cropping systems to inhibit weed growth within the cropping period.

\section{Physical Control}

Ragweed parthenium can be controlled with tillage during fallow periods. In plasticulture production, tillage between the plastic-covered beds can be effective if it occurs when the parthenium is in the early rosette stage. Hand weeding should occur no later than the earliest signs of bolting or flowering. Seed production may not be inhibited if weeds are pulled at later stages, particularly if pulled plants are deposited in the field. We recommend removal of hand-pulled plants to the field edges where more extensive control techniques are possible.

\section{Chemical Control PREEMERGENCE HERBICIDES}

Literature on the effectiveness of preemergence herbicides on ragweed parthenium control is inconsistent. The lack of consistency may be due to a variety of reasons, including differences in soil type, organic matter content, and application techniques, and variations between biotypes. In general terms pendimethalin provides poor control, flumioxazin and $S$-metolachlor provide suppression, and lactofen or metribuzin provide good control.

Tomato and Pepper: There are several preemergence options for tomato and pepper. Metribuzin can be used in tomato and provides excellent control when applied at 700 g a.i. ha ${ }^{-1}$ (1.25 pints acre ${ }^{-1}$ for Tricor $)($ Reddy et al. 2007). Unfortunately, only 1 pint acre ${ }^{-1}\left(560 \mathrm{~g}\right.$ a.i. ha $\left.{ }^{-1}\right)$ of metribuzin is registered preemergence in tomato, which may not be as effective as the 1.25 pints acre ${ }^{-1}$ rate. $S$-metolachlor (Dual Magnum ${ }^{\circ}$ ) can be used in tomato and pepper and should suppress emergence of parthenium when applied under the plastic mulch or in the row middles. Flumioxazin (Chateau ${ }^{\circ}$ ) and lactofen (Cobra ${ }^{\circ}$ can also be used in tomato and pepper and should suppress parthenium when applied in row middles. Adequate season-long control will likely require the addition of a postemergence herbicide.

Cucurbit: Herbicide options for cucurbits are very limited and vary with crop type. Flumioxazin is one option that can be applied preemergence in row middles in cucumber, muskmelon, watermelon, pumpkin, summer squash, and winter squash. Please contact your local UF/IFAS Extension agent for additional recommendations.

Strawberry: Flumioxazin (Chateau ) can be used in row middles and under plastic mulch for parthenium suppression. S-metolachlor (Dual Magnum ') will also suppress parthenium when applied in the row middles. The use of preemergence herbicides alone will not provide season-long control.

\section{POSTEMERGENCE HERBICIDES}

A variety of studies have reported that ragweed parthenium is susceptible to glyphosate (Roundup PowerMax and similar products) and paraquat (Gramoxone SL). However, glyphosate-resistant ragweed parthenium has been discovered in the Everglades Agricultural Area in southern Florida (Fernandez et al. 2015) as well as in tomato and strawberry fields in central Florida (personal observation). 
The population identified in the Everglades was resistant to rates 40x labelled rates (Fernandez et al. 2015). Lactofen (Cobra) is registered for use in rowmiddles for fruiting vegetable crops under 24(c) and is administered by Third Party Registrations, Inc., a subsidiary of the Florida Fruit and Vegetable Association. Glufosinate (Rely ${ }^{\circ}$ ) also provides control of ragweed parthenium but is not currently registered for use during crop production. Some formulations are labeled for fallow applications and may be of use in that regard.

Tomato and Pepper: In tomato, halosulfuron (Sandea ) has shown to be effective for postemergence control when applied at the rosette stage in some studies (Reddy et al. 2007), but no control was observed in preliminary trials conducted in Florida (N. Boyd, unpublished data). Trifloxysulfuron (Envoke) has demonstrated excellent control (95\%) when applied to the rosette stage and good control (86\%) when applied to the bolting stage (Reddy et al. 2007). Envoke may be applied post-directed to the transplanted tomatoes or in the row-middles. Lactofen (Cobra ${ }^{\circ}$ ) provides excellent control when applied to rosettes in row middles. Saflufenacil (Sharpen ${ }^{\circ}$ may be used postharvest on tomatoes or in the fallow period for control, although the label states it should be a maximum of $6 "$ tall. There are no postemergence options for pepper.

Cucurbit: Halosulfuron (Sandea ${ }^{\circ}$ is registered for cucumbers, cantaloupes, honeydews, pumpkins, and winter squash. Please consult the label for use patterns in directseeded and transplanted crops. However, halosulfuron efficacy on ragweed parthenium is inconsistent.

Strawberry: Clopyralid (Stinger) has shown excellent control when applied at the high label rate (Fernandez et al. 2015) and is registered for use atop the bed and in row middles.

\section{References}

Adkins, S., and A. Shabbir. 2014. "Biology, Ecology and Management of the Invasive Parthenium Weed (Parthenium hysterophorus L.)." Pest Manag. Sci. 70 (7): 1023-1029. https://doi.org/10.1002/ps.3708

Belgeri, A. M., C. N. Sheldon, and S. W. Adkins. 2012. "Screening Parthenium Weed (Parthenium hysterophorus L.) Seedlings for Their Allelopathic Potential." Pak. J. Weed Sci. Res. 18:727-731.
Crane, J. H., R. Stubblefield, and C. W. Meister. 2006. "Herbicide Efficacy to Control Parthenium (Parthenium hysterophorus) under Grove Conditions in Homestead, Florida." Proc. Florida State Hortic. Soc. 119:9-12.

Fernandez, J. V., D. C. Odero, G. E. MacDonald, J. Ferrell, and L. Gettys. 2015. "Confirmation, Characterization, and Management of Glyphosate-Resistant Ragweed Parthenium (Parthenium hysterophorus L.) in the Everglades Agricultural Area of South Florida." Weed Technol. 29 (2): 233-242. https://doi.org/10.1614/WT-D-14-00113.1

Kuar, M., N. K. Aggarwal, V. Kumar, and R. Dhiman. 2014. "Effects and Management of Parthenium hysterophorus: A Weed of Global Significance." Int. Sch. Res. Not. 2014:368647. https://doi.org/10.1155/2014/368647

Kumari, A., and R. K. Kohli. 1987. "Autotoxicity of Ragweed Parthenium (Parthenium hysterophorus)." Weed Sci. 35 (5): 629-632. https://doi.org/10.1017/S0043174500060690

Navie, S. C., R. E. McFadyen, F. D. Panetta, and S. W. Adkins. 1996. "The Biology of Australian Weeds. 27. Parthenium hysterophorus L.” Plant Prot. Q. 11:76-88.

Reddy, K. N., C. T. Bryson, and I. C. Burke. 2007. "Ragweed Parthenium (Parthenium hysterophorus) Control with Preemergence and Postemergence Herbicides." Weed Technol. 21 (4): 982-986. https://doi.org/10.1614/WT-07-053.1

Stamps, R. H. 2016. "Identification, Impacts, and Control of Ragweed Parthenium (Parthenium hysterophorus L.)." EDIS 2011 (6). https://edis.ifas.ufl.edu/publication/EP448 